\title{
Analysis of factors of production in the termination of feedlot lambs to pasture
}

\author{
[Análise de fatores de produção na terminação de cordeiros em confinamento a pasto] \\ L.C. Pereira ${ }^{1,5}$, L.C.V. Itavo ${ }^{2}$, R.G. Mateus ${ }^{1}$, L.A.B.M. Mendonça ${ }^{1}$, J.A.A. Costa ${ }^{3}$, \\ J.A.M. Bono ${ }^{4}$, M. Barbosa-Ferreira ${ }^{4}$, C.M.E. Carvalho ${ }^{1}$ \\ ${ }^{1}$ Universidade Católica Dom Bosco - Campo Grande, MS \\ ${ }^{2}$ Universidade Federal Mato Grosso do Sul - Campo Grande, MS \\ ${ }^{3}$ Embrapa Gado de Corte - Campo Grande, MS \\ ${ }^{4}$ Universidade Anhanguera Uniderp - Campo Grande, MS \\ ${ }^{5}$ Bolsista Capes/Fundect
}

\begin{abstract}
The objective of this study was to analyze the factors that influence the performance of lambs in pasture confinement, by substituting a concentrate with different levels of the aerial part of cassava in relation to hematocrit indices. The experiment was conducted at the Sheep Technology Center using 56 Pantaneira sheep, of which 28 were male and 28 were female. For female lambs, the globular volume showed a decreasing quadratic effect, with a minimum inclusion of $10.24 \%$ PAM in the diet for a hematocrit index of 32.28. A linear effect was observed for the mean crude protein intake in the male lambs based on the diet provided and was estimated to be equivalent to $87.4 \%$ of the lambs' final weight. In conclusion, mean crude protein consumption is most strongly correlated with the final weight of male lambs, and NDF is most strongly correlated with the final weight of female lambs, with the level of cyanide consumption influencing the average daily weight gain in female lambs. The hematocrit level of the male lambs decreased with an increase in the inclusion of the aerial part of cassava in the ration of the animals.
\end{abstract}

Keywords: Lambs, Famacha, hematocrit, nutrition

\section{RESUMO}

O objetivo do presente trabalho foi analisar os fatores de influência no desempenho de cordeiros em confinamento a pasto, com níveis de substituição de concentrado por parte aérea de mandioca, e sua relação com os índices de hematócritos. O experimento foi conduzido no Centro de Tecnologia de Ovinos (CTO), utilizando-se 56 ovinos da raça Pantaneira, sendo 28 machos e 28 fêmeas. No volume globular do grupo de fêmeas, observou-se efeito quadrático decrescente, com o ponto de mínimo para uma inclusão de 10,24\% de PAM na ração com índice de níveis de hematócritos de 32,28. O efeito linear observado para o consumo médio de PB no modelo para cordeiros machos, conforme a dieta fornecida, em função do peso final, foi estimada o equivalente a 87,4\% da formação do peso final dos cordeiros. Conclui-se que o consumo médio de proteína bruta é o fator com maior correlação com o peso final dos cordeiros machos e para as fêmeas o fator com maior correlação foi $F D N$, os nivveis de consumo de cianeto influenciaram no ganho de peso médio diário das fêmeas. O nível de hematócritos dos cordeiros machos foi reduzido com o aumento da inclusão da parte aérea da mandioca na ração dos animais.

Palavras-chave: cordeiros, nutrição, famacha, hematócritos

\section{INTRODUCTION}

Raising sheep in tropical pastures is challenging, due to the low availability of good-quality fodder during the year as a result of the seasonality of forage production. Several studies have investigated diets for lamb finishing in the field, to ensure sustainable activity and to increase meat production (Manera, et al., 2014).

Recebido em 27 de abril de 2017

Aceito em 17 de maio de 2018

E-mail: luizcp.agro@gmail.com - 
The aerial part of cassava is rich in nutrients and provides an interesting alternative strategy for partially replacing the grain components of the sheep diet, which consequently reduces production costs. It can be supplied in natura or conserved in the form of hay and silage, for the formulation of diets for lambs in pasture confinement (Modesto et al., 2004).

However, sheep kept in pastures are affected by gastrointestinal parasitism, resulting in significant economic losses related to sheep production and reduction in the productive potential of the animals due to anemia, which can lead to death (Tirabassi et al., 2013). Due to the frequency of treatment and misuse of antiparasitic drugs in sheep, there has been a reduction in the efficacy of these products in the main Brazilian producing regions, resulting in resistance to multiple anthelmintics (Molento, 2004).

Few studies have evaluated cassava shoot supplementation in relation to weight gain and the control of verminosis in sheep (Cano, 2009). The same author reported that sheep treated with cassava shoots exhibited a reduction in parasite load, a fact related to cyanide, which in small daily amounts, has phytotherapeutic action on gastrointestinal parasites.

Hematocrit values and the Famacha ${ }^{\circledR}$ test have been widely used as a reference for sheep. However, animals of different races, ages, sex, and place of rearing have diverse nutritional, energetic, and metabolic needs, which are reflected in their hematocrit profiles (Madureira et al., 2013). Besides the existence of several laboratory and clinical methods for parasitic diagnosis, the Famacha ${ }^{\circledR}$ test is easy to apply in the field, is associated with hematocrit value, and helps to control the incidence of acute infestations of the hematophagous parasite, Haemonchus contortus (Van Wyk et al., 1997). These auxiliary observations in the diagnosis of disease and its prevention can reduce economic losses related to the parasite.

Therefore, the objective of this study was to analyze factors influencing lamb performance in pasture confinement by substituting a concentrate with different levels of cassava, and to investigate its relationship with hematocrit indices.

\section{MATERIALS AND METHODS}

The experiment was carried out at the Center for Technology of Sheep (CTO) of the Manoel de Barros Foundation, in the municipality of Campo Grande - MS, at the following geographic coordinates: $29^{\circ} 33$ '51,96 "S and 54 32' 29,09". Research was authorized by the Anhanguera Educacional Ethics Committee on Animal Use Ltda.- CEUA / AESA - opinion: 2062. Fifty-six Pantaneira sheep were used, 28 males and 28 females, with a mean age of 75 days, and mean weight of $18.84 \mathrm{~kg} \pm 2.02$ for 65 days. The animals were kept on pasture with Panicum maximum cv. Massai with a 2.6-hectare area, subdivided into four pickets, with ad libitum water supply ad libitum and rations provided in two meals per day (8:30 am and 4:00 p.m.). All animals were previously weighed, identified, vermifuged, and subjected to ectoparasite control. To determine their performance, animals were weighed every 7 days following a 12-hour fast from solid foods.

A completely randomized experimental design was used, with four treatments, each including seven females and seven males. The rations used in the treatments were as follows: control (CT), concentrate based on corn and soybean meal with minerals; addition of $10 \%$ manioc aerial part in natura in substitute of concentrate (PAM 10 ); addition of $20 \%$ manioc in nature aerial part in substitute of concentrate (PAM 20); and addition of $30 \%$ manioc in natura instead of concentrate (PAM 30).

The aerial part of the cassava (PAM), constituting leaves, petiole, and branch, was minced and homogenized in a stationary chopper, left for 6 hours in the shade, and later used in natura. Adaptation was performed for 7 days before the start of the experiment.

The cassava variety IAC 576 was planted in May 2014. For that purpose, the spacing of one meter between 0.80-meter lines between plants was used, for a final population of 12,500 plants. Plants were fertilized with phosphorus, potassium, and nitrogen fertilizer 60 days after the emergence of cassava seedlings, according to the recommendations for fertilization of this crop (Raij et al., 1996). The aerial part was harvested 185 days after emergence (DAE), and the total 
aerial part of the plant was cut $20 \mathrm{~cm}$ from the ground.

To analyze the chemical composition and in vitro digestibility of the diets, weekly samples of the Panicum maximum cv. Massai, aerial part of cassava, and concentrate were obtained. After the biomass was sampled, samples from each date, type, and experimental group were sent to the Laboratory of Biotechnology Applied to Animal Nutrition of the University Católica Dom Bosco, and the dry matter (DM), organic matter (OM), and crude protein $(\mathrm{CP})$ levels were determined according to methodologies described by Silva and Queiroz (2006). Neutral detergent fiber (NDF) and acid detergent fiber (ADF) were determined according to methodologies described by Van Soest (1965). For the determination of in vitro digestibility (IVD), the technique described by Tilley and Terry (1963) adapted to an Artificial Rumen $\left(\mathrm{ANKOM}^{\circledR}\right)$, as detailed by Holden (1999) was used, with anaerobic ruminal fermenter methodology (model MA443, Marconi).

For the determination of cyanide, samples collected from the aerial part of the cassava (PAM) were conditioned in an icebox at the laboratory of the University Católica Dom Bosco (UCDB). The samples were separated and each fraction was identified. Residual cyanide levels in cassava shoots were determined using the alkaline Picrate method (Brito et al., 2013).

The control diet was composed of $60 \%$ concentrate and $40 \%$ bulk (Panicum maximum cv. Massai) pasture and was formulated to meet the nutritional requirements of lambs for a daily average weight gain of $0.200 \mathrm{~kg}$ (NRC, 2007) in pasture confinement, as estimated based on Table 1.

Table 1. Bromatological contents, in vitro digestibility, and cyanide content of manihot shoots (Manihot Esculenta Crantz), Panicum maximum cv. Massai and commercial concentrate for sheep

\begin{tabular}{cccc}
\hline Variables & $\begin{array}{c}\text { PAM } \\
\text { In natura }\end{array}$ & $\begin{array}{c}\text { Panicum } M \\
\text { cv. Massai }\end{array}$ & Concentrated \\
\hline DM (\%) & 29.21 & 31.04 & 84.37 \\
OM (\%) & 92.22 & 89.85 & 86.45 \\
CP (\%) & 14.10 & 12.74 & 21.00 \\
NDF (\%) & 58.63 & 74.70 & 17.92 \\
ADF (\%) & 40.25 & 42.45 & 11.08 \\
NDT (\%) & $59.33^{\mathrm{a}}$ & $52.63^{\mathrm{a}}$ & $80.23^{\mathrm{b}}$ \\
IVDMD (\%) & 62.27 & 58.64 & - \\
IVDOM (\%) & 95.27 & 89.71 & - \\
Cyanide (mg g & -1 & - & - \\
\hline
\end{tabular}

Aerial part of cassava (PAM); Panicum maximum cv. Massai (P. Massai); dry matter (DM); organic matter (OM); crude protein (CP); neutral detergent fiber (NDF); acid detergent fiber (ADF); total digestible nutrients (NDT); in vitro digestibility of dry matter (IVDMD); in vitro digestibility of organic matter (IVDOM), commercial concentrate

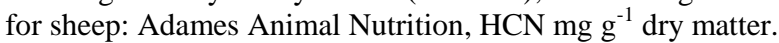

a: Estimated NDT of cane silage, according to Cappelle et al. (2001). NDT $=83.79-0.4171 \beta$ NDF

b: Estimated NDT of the concentrates according to Paterson (2000). NDT $=[88.9(0.779 \%$ ADF).

The following zootechnical indexes were calculated: final weight $(\mathrm{FW})$ and average daily weight gain (ADG). After animal performance was evaluated, the dry matter, NDF, ADF, protein, and cyanide intake was estimated from the intake of diets containing different levels of the cassava aerial part as a substitute for concentrate, according to the chemical composition of the nutrients, as shown in Table 1.

Globular volume (VG) and FAMACHA $^{\circledR}$ parameters were observed by mucosal examination with the aim of identifying animals with anemia. The examination was performed by comparing different shades, from rosy red to pale white conjunctiva, denoted by the numbers 1 to 5, and comparing them with a guide card developed for field use. Blood was collected at three periods into tubes containing the anticoagulant EDTA, and values for VG (\%) were determined via a microhematocrit technique by centrifugation according to the methodology described by Birgel (1982). 
Data were subjected to analysis of variance (ANOVA, $\mathrm{P}<0.05)$, linear regression analysis, multiple linear regression, multivariate analysis of the main component, and non-parametric Kruskal-Wallis test for the Famacha ${ }^{\circledR}$ indices. The statistical software SAS version 9.1 (2004) was used. Differences between treatment means were tested by the Tukey test $(\mathrm{P}<0.05 \%)$.

\section{RESULTS AND DISCUSSION}

The performance analysis revealed no differences $(\mathrm{P}<0.05)$ between treatments for FW and ADG, as shown in Table 2. The FW of male lambs was $29.68 \mathrm{~kg}$, and that of female lambs was $26.57 \mathrm{~kg}$, representing a mean difference of $3.11 \mathrm{~kg}$ (Table 2).
The ADG for male lambs was consistent with that observed by Catto et al. (2011) in pastureconfined animals, who gained an average of $169 \mathrm{~g} \mathrm{day}^{-1}$. However, the ADG values for female lambs were lower than those reported by Oliveira et al. (2013), at 221-210 $\mathrm{g} \mathrm{day}^{-1}$.

Therefore, animals fed diets containing 30\% PAM had a higher Famacha ${ }^{\circledR}$ value. However, the indices presented in the present study are higher than those observed by Jimenez-Sanz et al. (2016). According to Chagas et al. (2007), it is important to emphasize that the use of the Famacha ${ }^{\circledR}$ method must always be associated with an adequate diet for the animals.

Table 2. The performance of lambs in pasture confinement receiving diets with partial replacement of concentrate with the aerial part of cassava in natura for 65 days

\begin{tabular}{ccccccccc}
\hline Indexes & Control & PAM 10 & PAM 20 & PAM 30 & Equation & $\mathrm{R}^{2}$ & $\mathrm{P}$ \\
\hline \multicolumn{7}{c}{ Male } \\
\hline Final weight (kg) & 31.47 & 29.94 & 29.24 & 28.10 & $\mathrm{y}=$ & 29.68 & 0.98 & 0.155 \\
ADG (g) & 177 & 179 & 157 & 133 & $\mathrm{y}=$ & 161.5 & 0.86 & 0.588 \\
\hline \multicolumn{7}{c}{ Female } \\
\hline Final weight (kg) & 26.75 & 25.41 & 26.72 & 27.38 & $\mathrm{y}=$ & 26.57 & 0.73 & 0.427 \\
ADG (g) & 120 & 105 & 134 & 121 & $\mathrm{y}=$ & 120 & 0.12 & 0.786 \\
\hline
\end{tabular}

Average daily weight gain (ADG); $\mathrm{P}<0.05$.

A significant effect $(\mathrm{P}<0.05)$ was observed for Famacha ${ }^{\circledR}$ evaluations in relation to treatment for female lambs (Table 3).

Table 3. Average Famacha ${ }^{\circledR}$ levels for lambs in pasture confinement receiving diets with partial replacement of concentrate by the aerial part of cassava in natura for 65 days

\begin{tabular}{lccccc}
\hline Indexes & Control & PAM 10 & PAM 20 & PAM 30 & P \\
\hline Male & 2.09 & 2.14 & 2.23 & 2.33 & 0.491 \\
Female & $1.85 \mathrm{a}$ & $2.11 \mathrm{~b}$ & $2.08 \mathrm{~b}$ & $2.33 \mathrm{~b}$ & 0.027 \\
\hline
\end{tabular}

Mean values in the same line with different lowercase letters represent a significant treatment effect by the KruskalWallis test $(\mathrm{P}<0.05)$.

Regarding the globular volume (VG), a decreasing quadratic effect $(\mathrm{P}<0.01)$ was observed, with a minimum inclusion of $10.24 \%$ PAM in the diet with a hematocrit level index of 32.28 (Table 4). For male lambs, no differences $(\mathrm{P}<0.05)$ were observed for $\mathrm{VG}$ indices between treatments. The mean values obtained for the hematocrit levels in male and female lambs were similar to those obtained in previous studies, and to indices considered normal on the erythrocyte mass curve and for plasma volume (Madureira et al. 2013).

Table 4. Mean levels of globular volume for lambs in pasture confinement receiving diets containing with partial replacement of concentrate by the aerial part of cassava in natura for 65 days

\begin{tabular}{lccccccc} 
Indexes & Control & PAM 10 & PAM 20 & PAM 30 & Equation & $\mathrm{R}^{2}$ & $\mathrm{P}$ \\
\hline Male & 33.52 & 34.41 & 33.14 & 34.95 & $\mathrm{y}=34.01$ & 0.22 & 0.633 \\
Female & 33.11 & 31.97 & 33.25 & 34.87 & $\mathrm{y}=0.0069 \mathrm{x}^{2}-0.1414 \mathrm{x}+33.006$ & 0.95 & 0.001 \\
\hline \multicolumn{7}{l}{ Globular volume (VG); P - treatment effect $(\mathrm{P}<0.05)}$.
\end{tabular}


The mean estimated DM consumption decreased linearly $(\mathrm{P}<0.05)$ for the male lambs, representing a reduction in consumption of $192 \mathrm{~g}$ $\mathrm{day}^{-1}$ in relation to the PAM30 treatment. For the female lambs, a quadratic effect was observed $(\mathrm{P}<0.05)$ with a minimum consumption of $612 \mathrm{~g}$ day $^{-1}$ with the inclusion of $26.34 \%$ PAM (Table 5). However, the lowest consumption did not result in a significant difference in the $\mathrm{FW}$ of the animals during the experimental period (Table 2).
It should be noted that the percentage of DM reduction also influenced crude protein $(\mathrm{CP})$ consumption by the male lambs, for which a negative quadratic effect $(\mathrm{P}<0.05)$ was observed, with the lowest consumption (159.82g day $^{-1}$ ) observed with the inclusion of $26.41 \%$ PAM (Table 5). However, the reduction in DM did not affect $\mathrm{CP}$ consumption ( $\mathrm{P}>$ 0.05) among experimental groups of female lambs.

Table 5. Estimates of daily intake of dry matter (DM), crude protein (CP), neutral detergent fiber (NDF), acid detergent fiber (ADF), and cyanide by lambs in pasture confinement receiving diets containing partial replacement of the concentrate for the aerial part of cassava in natura for 65 days

\begin{tabular}{|c|c|c|c|c|c|c|c|c|}
\hline Indexes & Control & PAM 10 & PAM 20 & PAM 30 & & Equation & $\mathrm{R}^{2}$ & $\mathrm{P}$ \\
\hline \multicolumn{9}{|c|}{ Male } \\
\hline CM DM (g animal $\left.{ }^{-1}\right)$ & 799 & 709 & 635 & 607 & $y=$ & $-6.5 * x+785$ & 0.99 & 0.001 \\
\hline CM CP $\left(\right.$ g animal $\left.^{-1}\right)$ & 181 & 167 & 162 & 160 & $y=$ & $180.7+-1.5799 * \mathrm{x}+0.0299 * \mathrm{x}^{2}$ & 0.99 & 0.031 \\
\hline CM NDF $\left(\mathrm{g}\right.$ animal $\left.^{-1}\right)$ & 231 & 218 & 213 & 212 & $y=$ & 218.50 & 0.83 & 0.267 \\
\hline CM ADF $\left(\mathrm{g}\right.$ animal $\left.^{-1}\right)$ & 138 & 126 & 121 & 117 & $y=$ & $-6.9714 \mathrm{e}^{-4} * \mathrm{x}+0.1362$ & 0.98 & 0.006 \\
\hline CM NDT $\left(\mathrm{g}_{\text {animal }}{ }^{-1}\right)$ & 597 & 522 & 476 & 435 & $y=$ & $-5.32 x+587.3$ & 0.97 & 0.001 \\
\hline Cyanide $\mathrm{mg} \mathrm{g}^{-1}$ & 0 & 0,030 & 0,059 & 0,088 & $y=$ & $0,002939 * x+4,3303 \mathrm{e}^{-4}$ & 0.97 & 0.001 \\
\hline \multicolumn{9}{|c|}{ Female } \\
\hline CM DM (g animal $\left.{ }^{-1}\right)$ & 728 & 640 & 634 & 614 & $y=$ & $723+-8.4004 * \mathrm{x}+0.1601 * \mathrm{x}^{2}$ & 0.93 & 0.001 \\
\hline CM CP $\left(\right.$ g animal $\left.^{-1}\right)$ & 164 & 151 & 156 & 160 & $y=$ & 157.75 & 0.80 & 0.203 \\
\hline CM NDF $\left(\right.$ g animal $\left.^{-1}\right)$ & 211 & 196 & 205 & 213 & $y=$ & 206.25 & 0.82 & 0.279 \\
\hline CM ADF (g animal $\left.{ }^{-1}\right)$ & 126 & 114 & 116 & 118 & $y=$ & 119 & 0.82 & 0.163 \\
\hline CM NDT $\left(\mathrm{g}\right.$ animal $\left.^{-1}\right)$ & 544 & 472 & 463 & 437 & $y=$ & $-3.3 x+528.5$ & 0.86 & 0.001 \\
\hline Cyanide $\mathrm{mg} \mathrm{g}^{-1}$ & 0 & 0.027 & 0.054 & 0.089 & $y=$ & $0.0029297 * \mathrm{x}+-0.0014459$ & 0.95 & 0.001 \\
\hline
\end{tabular}

Average dry matter consumption (CM DM); average crude protein consumption (CM CP); average NDF consumption (CM NDF); average consumption of FDA (CM ADF); $\mathrm{P}$ - treatment effect $(\mathrm{P}<0.05)$.

Higher levels of PAM in the treatments favored a linear effect $(\mathrm{P}<0.05)$ in relation to cyanide consumption among the groups studied (Table $5)$. There was no linear or quadratic effect for the other consumption parameters analyzed.

Values for the ADF consumption of the total DM presented a negative linear $(\mathrm{P}<0.05)$ effect for male lambs with higher PAM inclusion (Table 5), possibly due to the chemical composition of this diet and the coarser fractions. The same performance was observed among the different rates of PAM inclusion in the diet, which favored increased nitrogen release for microbial protein synthesis (Detmann et al, 2014) due to greater masticatory activity, resulting in greater buffering capacity.

Correlations between production factors among the studied characteristics are presented in Figure 1 , which shows that in the main component matrix, the total variance explained was 84.57 and $84.66 \%$ for male and female lambs, respectively. The eigenvalues indicate that two components can provide a summary of the physiological states and performance of the animals. These results indicate that the male lambs in group 1 explain $60.87 \%$ of the observed variation among the characteristics, and that the final weight of the animals is highly related to the consumption of DM, CP, and NDF (Figure 1).

Group 2 was characterized by the consumption of PAM, which was directly correlated with the consumption of cyanide and influenced the Famacha $^{\circledR}$ indexes (Figure 1). Conversely, the two clusters were influenced by the VG index, which denotes the physiological state of the lambs. However, when evaluating associations for the female lambs, there was no significant correlation between VG and the other parameters analyzed in this study. 

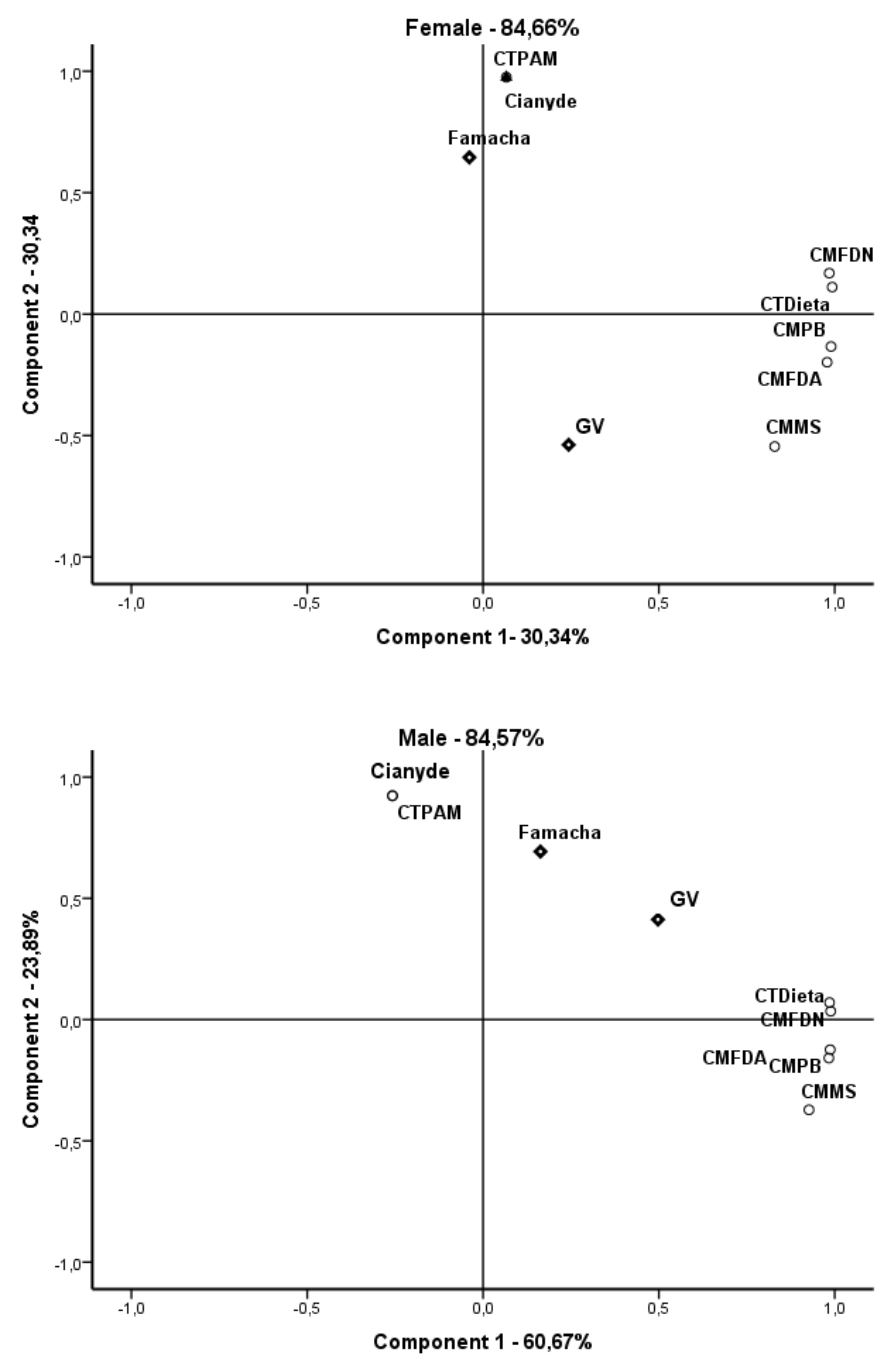

Figure 1. Variation observed between the main components for male (left) and female lambs (right) for the factors: total diet consumption (CT Dieta), total consumption of cassava shoots (CT PAM), cyanide, Famacha, globular volume $(\mathrm{GV})$, mean dry matter intake (CM DM), mean crude protein consumption (CM CP), mean neutral detergent fiber consumption (CM NDF) mean consumption of acid detergent fiber (CM ADF), and final weight.

Based on the results found in the main component analysis, it was possible to apply a multiple regression to identify the most important factor within the model, correlated with the productivity indexes of FW and ADG of lambs.

Protein and NDF consumption generated a quadratic positive effect $(\mathrm{P}<0.05)$ for male and female lambs, respectively (Figure 2). The factors that did not show a significant linear effect in the regression equation of the model for the FW composition of lambs were as follows: $\mathrm{FW}$ male $=5.96+130.02 \mathrm{CM} \mathrm{CP} ; \mathrm{FW}$ females $=$ $2.776+114.62 *$ FDN.

A linear effect was observed for mean $\mathrm{CP}$ intake in the model for male lambs according to the diet provided, as a function of the $\mathrm{FW}$, and was estimated to be equivalent to $87.4 \%$ of the lambs' final weight. In female lambs, the equivalent observed NDF consumption factor was $88.2 \%$ of the final weight formation. 

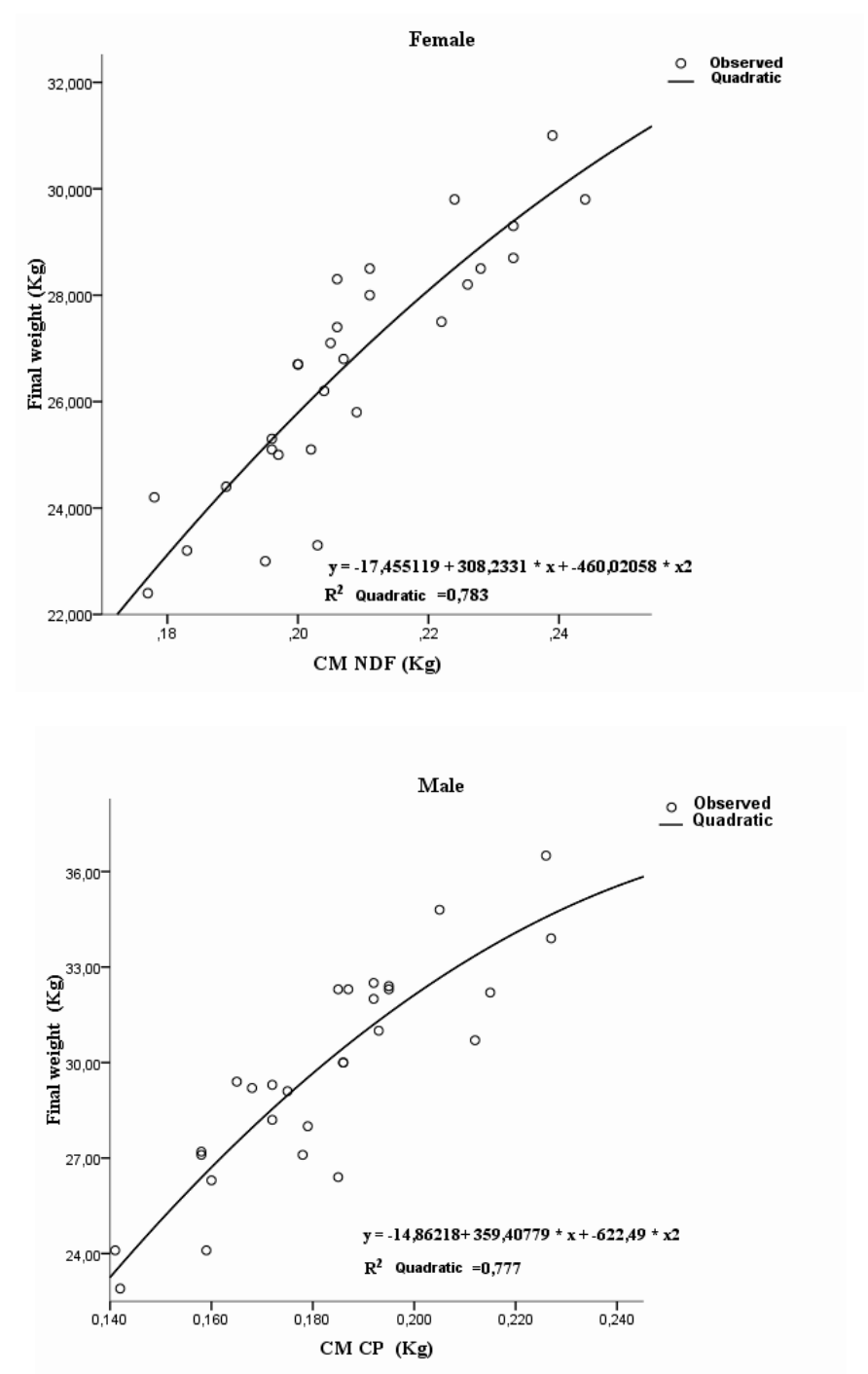

Figure 2. Relationship between final lamb weight in the feedlot pasture and the average crude protein intake for male lambs (left), and average NDF intake for female lambs (right).

The model proposed for ADG presented the following equation for male and female lambs: male $\mathrm{ADG}=0.187+0.831 * \mathrm{CM} \mathrm{CP}-0.06 \mathrm{VG}$; ADG females $=0.095+0.418 *$ CYANIDE. The values for $\mathrm{CM}, \mathrm{CP}$, and $\mathrm{VG}$ are equivalent to 56.4 and $49.3 \%$ of the model for male lambs as a function of ADG. In the model presented for female lambs, cyanide predicts $61.2 \%$ of the ADG results. In view of the proposed models, there was a higher demand for $\mathrm{CP}$ by male lambs. Considering the value for the maintenance of metabolizable protein (PMm) and metabolizable growth protein (PMc) requirements (Table 6), and the fact that the greatest contribution of dietary protein to muscle formation (Owens et al., 1993), in relation to the physiological phase of the animals. The other factors had no effect $(\mathrm{P}>0.05)$ in the models studied.

The values corresponding to the $\mathrm{GV}$, which showed a negative quadratic effect $(\mathrm{P}<0.05)$, are related to the physiological state (Pereira et al., 2015) of the animals, such that during the experimental period their resistance increased due to diet provided, maintaining the normal levels (David et al., 2012). 


\section{Pereira et al.}
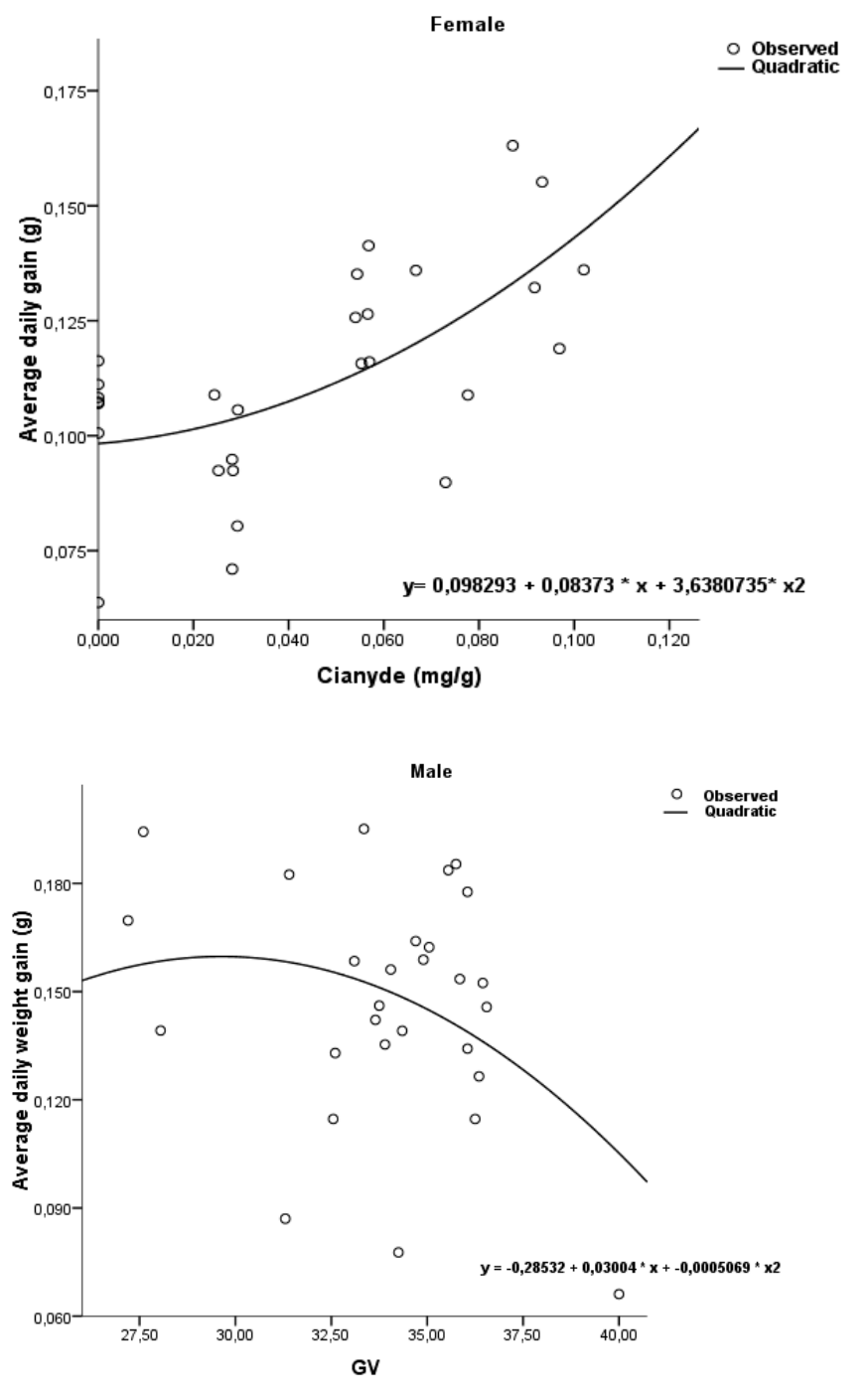

Figure 3. Relationship between average daily gain (ADG) of lambs in pasture confinement and globular volume (GV) for male lambs (left), and cyanide consumption for female lambs (right).

According to Paulino et al (2004), the productive response to supplementation is related to the animal, pasture, physiological state, health, and desired performance. A possible justification for the female model has an effect on NDF consumption, it is possible to hypothesize the higher demand for average metabolizable energy (ME) (40.99Mcal). Similarly, the metabolic weight $(11.70 \mathrm{~kg})$ was higher for female lambs than for male lambs, who obtained a mean $39.85 \mathrm{Mcal}$ of DM (Table 6) to reach the PF.
In addition to the influence of sexual factors related to body maturity, Morais et al. (2016) reported that crossbreeding with Pantaneira breed resulted in the early deposition of body fat, which is related to the demand for EMg. The authors also reported that the metabolizable maintenance requirements of supplements make it possible to maintain the physiological processes associated with visceral metabolism as well as the synthesis and deposition of tissues and fat in the carcass. 
Table 6. Metabolizable energy values for maintenance (EMm), metabolizable energy for gain (EMg), metabolizable energy (EM), metabolizable protein for maintenance (PMm), and metabolizable protein growth $(\mathrm{PMc})$ of lambs in pasture confinement receiving diets with the concentrate partially replaced by the aerial part of manioc in natura for 65 days

\begin{tabular}{|c|c|c|c|c|c|c|c|}
\hline Indexes & Control & PAM 10 & PAM 20 & PAM 30 & Equation & $\mathrm{R}^{2}$ & $\mathrm{P}$ \\
\hline \multicolumn{8}{|c|}{ Male } \\
\hline EMm (Mcal dia $\left.{ }^{-1}\right)$ & 1.818 & 1.750 & 1.719 & 1.667 & $y=-0.0048 x+1.8113$ & 0.98 & 0.011 \\
\hline EMg (Mcal dia $\left.{ }^{-1}\right)$ & 1.139 & 1.106 & 0.952 & 0.781 & $y=-0.0123 x+1.1794$ & 0.93 & 0.032 \\
\hline $\operatorname{ME}\left(\mathrm{Mcal} \mathrm{dia}^{-1}\right)$ & 2.957 & 2.857 & 2.671 & 2.449 & $y=-0.0171 x+2.9907$ & 0.97 & 0.013 \\
\hline $\operatorname{PMm}\left(\mathrm{g} \mathrm{PB} \mathrm{dia}{ }^{-1}\right)$ & 29.065 & 27.998 & 27.506 & 26.697 & $y=-0.0759 x+28.956$ & 0.98 & 0.011 \\
\hline PMc $\left(\mathrm{g} \mathrm{dia}^{-1}\right)$ & 39.723 & 40.439 & 35.580 & 30.300 & $y=-0.3313 x+41.48$ & 0.85 & 0.044 \\
\hline \multicolumn{8}{|c|}{ Female } \\
\hline EMm (Mcal dia $\left.{ }^{-1}\right)$ & 1.606 & 1.544 & 1.604 & 1.634 & $y=0.0015 x+1.5755$ & 0.25 & 0.050 \\
\hline EMg (Mcal dia $\left.{ }^{-1}\right)$ & 0.678 & 0.569 & 0.756 & 0.696 & $y=0.0024 x+0.6391$ & 0.16 & 0.042 \\
\hline ME (Mcal dia $\left.{ }^{-1}\right)$ & 2.284 & 2.114 & 2.361 & 2.331 & $y=0.0039 x+2.2146$ & 0.21 & 0.047 \\
\hline $\operatorname{PMm}\left(\mathrm{g} \mathrm{PB} \mathrm{dia}^{-1}\right)$ & 25.730 & 24.753 & 25.708 & 26.183 & $y=25.59$ & 0.25 & 0.057 \\
\hline PMc $\left(\mathrm{g} \mathrm{dia}^{-1}\right)$ & 26.747 & 24.043 & 28.651 & 24.374 & $y=25.95$ & 0.02 & 0.582 \\
\hline
\end{tabular}

$\mathrm{P}$ - Treatment effect $(\mathrm{P}<0.05)$. Metabolizable maintenance energy: $\mathrm{EMm}=(\mathrm{ELm}+\mathrm{A}) / \mathrm{km}, \mathrm{A}(\mathrm{kJ} / \mathrm{day})=6.7 \mathrm{PV}$ and $\mathrm{km}=0.5$ and for calculations of metabolizable maintenance liquid energy (ELm) = FCS (PV/1.08) 0.75; sex correction factor $(\mathrm{FCS})=1.15$ for males and 1 for females; $(\mathrm{Mg} / \mathrm{Kg})=2.5+0$, and the metabolizable net gain energy $(\mathrm{ELg})=(\mathrm{GMD}(\mathrm{kg}) \times \mathrm{VEG}) 35 \mathrm{PV}$; For castrated males, $[\mathrm{VEG}](\mathrm{MJ} / \mathrm{kg})=4.4+0.32 \mathrm{PV}$ is used, and for females, $[\mathrm{VEG}](\mathrm{MJ} / \mathrm{Kg})=2.1+0.45 \mathrm{PV}$ is used; Metabolizable energy $(\mathrm{ME})=\mathrm{EMm}+\mathrm{EMg}$; Meta-maintainable protein $(\mathrm{PMm})(\mathrm{g}$ of N/day $)=0.35 \times \mathrm{PV} 0.75$, we multiplied $6.25 * \mathrm{~N}$ to obtain CP levels; Growth metabolizable protein for males: $(\mathrm{PMc})=1.695(\mathrm{GPV}, \mathrm{kg})(160.4-1.22 \mathrm{PV}+0.0105$ PV2), and for females: $(\mathrm{PMc})=1.695 \mathrm{GPV}(156.1-1.94$ PV + 0.0173 PV2); 1 Mcal=4,184 MJ; calculated according to AFRC methodology (1993).

With respect to the quadratic effect $(\mathrm{P}<0.05)$ for cyanide increasing as a function of ADG for female lambs (Figure 3), this is possibly correlated with PAM protein. This relationship with cyanide is positively correlated with the increase in $\mathrm{N}$ levels, since $\mathrm{CP}$ is composed of nitrogen compounds. Therefore, ingestive behavior and PAM consumption are correlated to animal performance as demonstrated in the proposed model.

Supplementation of grazing animals is the act of providing the system with a source of additional nutrients, and this would be reflected in changes in feed intake, nutrient concentrations, dietary energy availability, magnitude of the biochemical precursor pools of metabolism, and animal performance (Paulino et al., 2004). Other studies have shown that animals fed diets with high CP levels have a higher immunological capacity to respond to gastrointestinal nematode infections (Molento, 2004).

\section{CONCLUSION}

In conclusion, the mean $\mathrm{CP}$ intake had the highest correlation with the FW of male lambs, and NDF had the highest correlation with the FW of female lambs. The level of cyanide consumption influenced the average daily weight gain of the female lambs. The hematocrit level of the male lambs decreased with increasing levels of the aerial part of the cassava included in the animal ration.

\section{REFERENCES}

BIRGEL, E.H. Hematologia clínica veterinária. In: BIRGEL, E.H.; LARSSON, M.H.M.A.; HAGIWARA, M.K. Patologia clínica veterinária. São Paulo: Sociedade Paulista de Medicina Veterinária, 1982. p.2-49.

BRITO, O.R.; RABACOW, A.P.M.; CEREDA, M.P. Classification of nine month-old cassava cultivars by cyanide levels. Gene Conserv., v.12, p.35-49, 2013.

CANO, M.A.S. Efeito da suplementação com Manihot esculenta crantz, sobre o desempenho animal e carga parasitária em ovinos em crescimento. 2009. 113f. Dissertação (Mestrado em Zootecnia) - Universidade Federal do Rio Grande do Sul, Faculdade de Agronomia, Porto Alelgre, RS.

CATTO, J.B.; REIS, F.A.; FERNANDES, L.H. et al. Ganho de peso e parasitismo por nematódeos gastrintestinais em cordeiros terminados em confinamento ou em pastagem diferida: estudo piloto. In: SIMPÓSIO INTERNACIONAL SOBRE CAPRINOS E OVINOS DE CORTE, 5., 2011, João Pessoa. Anais... João Pessoa: PB, 2011. 
CHAGAS, A.C.S.; OLIVEIRA, M.D.S.; FERNANDES, L.B. et al. Controle da verminose, mineralização, reprodução e cruzamentos de ovinos na Embrapa Pecuária Sudeste. Cidade: Embrapa Pecuária Sudeste, 2007. v.1, p.44.

DAVID, C.M.G.; LUQUETTI, B.C.; DA COSTA, R.L.D.; BONELLO, F.L. Padrão hematológico de cordeiros da raça Santa Inês criados sob manejo semiextensivo na região oeste do estado de São Paulo. Bol. Ind. Anim., v.69, p.79-84, 2012.

DETMANN, E.; PAULINO, M. F.; VALADARES FILHO, S. C.; HUHTANEN, P. Nutritional aspects applied to grazing cattle in the tropics: a review based on Brazilian results. Semina: Agricultural Sciences, Londrina, v. 35, n. 4, p. 2829-2854, 2014.

HOLDEN, L. A. Comparison of methods of in vitro dry matter digestibility for ten feeds. Journal of Dairy Science, v. 82, n. 8, p. 1791-1794, 1999.

HOSMER, D.W.; LEMESHOW, S. Applied logistic regression. 2.ed. New York: John Wiley \& Sons, 2000. 375p.

JIMENEZ-SANZ, A.L.; QUIRINO, C.R.; PACHECO, A. et al. Relação entre fatores associados às parasitoses gastrointestinais, desempenho e estado fisiológico de ovelhas Santa Inês. Agropecu. Téc., v.37, p88-95, 2016.

MADUREIRA, K.M.; MEDICI MADUREIRA, K., GOMES, V.; BARCELOS, B. et al. Parâmetros hematológicos e bioquímicos de ovinos da raça Dorper. Semin. Ciênc. Agrár., v.34, p.811-816, 2013.

MANERA, D.B.; VINHAS VOLTOLINI, T.; YAMAMOTO, S.M. et al. Desempenho produtivo de ovinos em pastejo suplementados com concentrados contendo coprodutos do processamento de frutas. Semin. Ciênc. Agrár., v.35, p.1013-1022, 2014.

MODESTO, E.C.; SANTOS, G.T.; VILELA, D. et al. Caracterização químico-bromatológica da silagem do terço superior da rama de mandioca. Acta Sci. Anim. Sci., v.26, p.137-146, 2004.

MOLENTO, M.B. Resistência de helmintos em ovinos e caprinos. Rev. Bras. Parasitol. Vet., v.13, p.82-87, 2004.MORAIS, M.G. Exigências de energia de borregas mestiças alimentadas com níveis crescentes de concentrado na dieta. Arq. Bras. Med. Vet. Zootec., v.68, p.1023-1032, 2016.

NUTRIENT requirements of small ruminants. Washington: National Academy Press, 2007.

OLIVEIRA, M.V.; FERREIRA, I.C.; JÚNIOR, G.D.L.M.; et al. Benefícios do uso da monensina sódica na nutrição de cordeiros semi-confinados. Biosci. J., v.29, p.1961-1970, 2013.
OWENS, F.N.; DUBESKI, P.; HANSON, C.F. Factors that alter the growth and development of ruminants. J. Anim. Sci., v.71, p.3138-3150, 1993.

PATTERSON, T.; KLOPFENSTEIN, T.J.; MILTON, T.; BRINK, D.R. Evaluation of the 1996 beef cattle NRC model predictions of intake and gain for calves fed low or medium energy density diets. Nebraska beef. Report MP 73-A, p.26-29, 2000.

PAULINO, M.F.; FIGUEIREDO, D.D.; MORAES, E.H.B.K. et al. Suplementação de bovinos em pastagens: uma visão sistêmica. In: SIMPÓSIO DE PRODUÇÃO DE GADO DE CORTE, 4., 2004, Viçosa. Anais... Viçosa: SIMCORTE, 2004. p.93-139.

PEREIRA, F.B.; BEZERRA, L.R.; MARQUES, C.A.T. et al. Hematological profile of Santa Inês ewes supplemented on pasture at the last third of pregnancy and postpartum. Ciênc. Anim. Bras., v.16, p.350-357, 2015.

RAIJ, B.; CANTARELLA, H.; QUAGGIO, J.A.; FURLANI, A.M. (Eds.). Recomendações de adubação e calagem para o estado de São Paulo. 2.ed. Campinas: IAC, 1997. 285p. (Boletim Técnico, 100).

REZENDE, C.E.; VALADARES, F.S.D.C.; ROBERTO, C.P. Estimativas do valor energético a partir de características químicas e bromatológicas dos alimentos. Rev. Bras. Zootec., v.30, p.1837-1856, 2001.

SAS/STAT user's guide: version 9.1. North Caroline: SAS Institute, 2004. 5136p.

SILVA, D. J.; QUEIROZ, A. C. de. Análise de alimentos: métodos químicos e biológicos. 3.ed. Viçosa: UFV, 2006. 235 p.

TILLEY, J.M.A.; TERRY, R. A two-stage technique for the in vitro digestion of forage crops. J. Br. Grassl. Soc., v.18, p.104-111, 1963.

TIRABASSI, A.H.; MADEIRA, H.M.F.; OLLHOFF, R.D.; SOTOMAIOR, C.S. Manejo integrado de parasitos como alternativa sustentável na produção de pequenos ruminantes. Rev. Acad. Ciênc. Agrár. Amb., v.11, p.322-338, 2013.

VAN SOEST, P.J. Voluntary intake relation to chemical composition and digestibility. J. Anim. Sci., v.24, p.834-844, 1965.

VAN WYK, J.A.; MALAN, F.S.; RANDLES, J.L. How long before resistance makes it impossible to control some field strains of Haemonchus contortus in South Africa with any of the modern anthelmintics. Vet. Parasitol., v.70, p.111-122, 1997. 